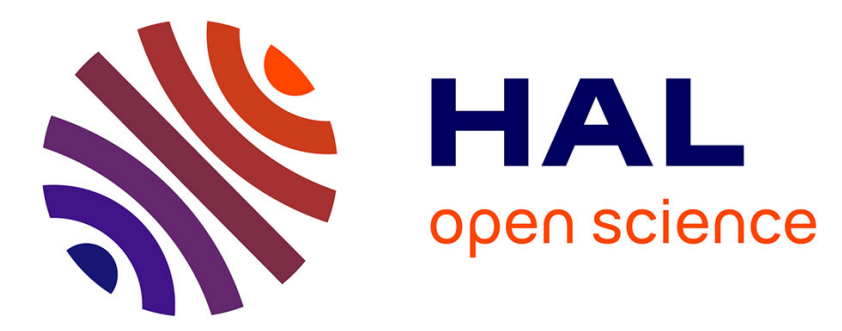

\title{
Bacteria electrical detection using 3D silicon nanowires based resistor
}

Brice Le Borgne, Laurent Pichon, Anne-Claire Salaün, Baptiste Le Bihan, Anne Jolivet-Gougeon, Sophie Martin, Regis Rogel, Olivier de Sagazan

\section{- To cite this version:}

Brice Le Borgne, Laurent Pichon, Anne-Claire Salaün, Baptiste Le Bihan, Anne Jolivet-Gougeon, et al. Bacteria electrical detection using 3D silicon nanowires based resistor. Sensors and Actuators B: Chemical, 2018, 273, pp.1794-1799. 10.1016/j.snb.2018.07.101 . hal-01860675

\section{HAL Id: hal-01860675}

\section{https://hal-univ-rennes1.archives-ouvertes.fr/hal-01860675}

Submitted on 23 Aug 2018

HAL is a multi-disciplinary open access archive for the deposit and dissemination of scientific research documents, whether they are published or not. The documents may come from teaching and research institutions in France or abroad, or from public or private research centers.
L'archive ouverte pluridisciplinaire $\mathbf{H A L}$, est destinée au dépôt et à la diffusion de documents scientifiques de niveau recherche, publiés ou non, émanant des établissements d'enseignement et de recherche français ou étrangers, des laboratoires publics ou privés. 


\section{Bacteria electrical detection using 3D silicon nanowires based resistor}

Brice Le Borgne $^{1}$, Laurent Pichon ${ }^{1 *}$, Anne Claire Salaun ${ }^{1}$, Baptiste Le Bihan ${ }^{1}$, Anne JolivetGougeon $^{2}$, Sophie Martin ${ }^{3}$, Regis Rogel ${ }^{1}$ and Olivier de Sagazan ${ }^{1}$

${ }^{1}$ Institut d'Electronique et de Télécommunications de Rennes, IETR UMR CNRS 6164, Université de Rennes 1, Rennes, France,

2 Nutrition Métabolisme et Cancer, NuMeCan UMR INSERM 1241, Université de Rennes 1, Rennes, France

${ }^{3}$ Société ARCLYNN, Missillac, France

*corresponding author: 1pichon@univ-rennes1.fr, , tel: +332 232356 65, fax:+332 23235657

Resistors based on silicon nanowires (SiNWs) are developed for the direct detection of Escherichia coli bacteria. The devices are manufactured using conventional silicon technology. The SiNWs are synthesized by the vapor liquid solid process (VLS) using gold as the catalyst. The electrodes of the device consist of highly in situ doped polycrystalline silicon. The results show that the corresponding resistances can be potentially used for the detection of bacteria by electrical measurements, using SiNWs as sensitive units. The bacteria are preferentially hooked in the SiNWs network, which causes a drastic reduction in the electrical resistance of the component. Such resistor manufactured in a simple and low-cost CMOS (Complementary Metal Oxide Semiconductor) technology acts as proof of concept. This device offers promising potentialities taking advantages of integration into CMOS 
platform for alternative direct electrical detection of bacteria to monitor the contamination in environment for hygiene applications.

\section{Introduction}

One of the main challenges in terms of a public health is the rapid detection of bacteria in food, water and air, particularly because of the emergence of multi-resistant bacteria. Although standard microbiological cell culture for identifying bacterial strains are well controlled, the detection process can often take several days. In addition, complex instrumentation [1] is required in most conventional methods, and cannot be used on site. Classical methods for the detection of pathogens are polymerase chain reaction (PCR) [2], colony culture and enumeration methods [3], immunological methods [4] and more recently detection of pathogens bacteria using mass spectrometry [5]. The main drawbacks of these methods are significant analysis time, high cost equipment, and complexity of detection process.

The use of biosensors [6] is an alternative method for detecting bacteria combining a biological recognition mechanism with a physical transduction technique. In this case transduction may be micromechanical, electrochemical, piezoelectric, thermometric, magnetic or optical. In particular, the electrochemical transduction methods such as amperometry [7], impedance spectroscopy [8-10], potentiometry [11], are much faster and more sensitive than other techniques.

Bacteria detection systems are based on multidisciplinary fields requiring knowledge of physics, chemistry, biology, instrumentation, microelectronics and fabrication technology. In the objective of a lab on chip system for rapid detection of bacteria which may revolutionize health prevention, the challenge is the development of low cost and high sensitive new 
sensors that enable direct bacteria detection at low level. But none of the detection methods previously reported fulfils all these criteria.

However, electrical detection of charged (bio)chemical species or polar molecules by measurement of the conductance change could be an alternative approach. Indeed, conductance variation, due to the charge effect facilitated by positioning species between two interconnected electrodes, preserves high sensitivity with less detection time [12]. In addition, based on this detection method, many groups have reported on field effect transistors (FET) used as biochemical sensors. In particular, chemical or biochemical (DNA hybridization) [13, 14], gas [15] or mechanical [16] sensors, have been demonstrated using silicon nanowires (SiNWs) based FETs. In this case nanowires act as sensing elements. However, few works report on SiNWs use as great promising method for label free, ultra-sensitive and real-time detection of bacteria $[17,18]$

The recent progress in micro- and nano-technologies for fabrication of nano-objects compatible with silicon technology offer great opportunities for the development of innovative biosensors integrated on CMOS (Complementary Metal Oxide Semiconductor) platforms. These sensors could be interestingly directly coupled with any existing circuitry or signal conditioning systems to transmit their output data. Furthermore, due to their specific properties at nanoscale (high surface/volume ratio, carrier confinement), SiNWs are promising candidates as sensing elements for high sensitive bacteria detection at low level. The main advantages of the use of such nano-objects are: the possibility of the mass production, the use of the volume of materials at low level, the micro-fluidic facilities for transport of reagents, the reduction of analysis time, and thus the reduced costs of fabrication and analysis.

However, the development of a small sized, reliable and versatile low-cost sensor based on nanowires has not been yet demonstrated. Indeed, many previous studies based on materials, 
structures and functionalization are reported into literature, but the proposed solutions do not fulfill the requirements for integration into a sensor. The major problem is the realization of such high-performance sensor with a low-cost technology, while the technological means used for the realization of nanowires require high cost and complex technologies based on ebeam lithography [14] or transfer techniques [19]. Nevertheless, alternative self-assembly methods [20] are promising for synthesis of nanowires and do not require expensive lithographic tools.

Moreover, many chemical or biological silicon nanowires based sensors are issued from field effect transistor technology, but the manufacturing process includes many fabrication steps (at least four masks for lithography), with possible transfer techniques and sophisticated chemical steps for functionalization. On the other hand, the fabrication of sensors based on basic electronic devices (for instance resistors, capacitors), with direct integration of the nanowires as sensing elements, refers as simple and low-cost technology and constitutes a technological progress.

In this way, in this study the feasibility of SiNWs based resistor for bacteria detection with SiNWs used as sensing elements synthesized by vapour liquid solid (VLS) mechanism [20] (self-assembly method) is investigated. Such device acts as proof of concept and fulfills the following requirements: i) low cost technology, ii) high sensitivity, iii) real-time analysis, iv) electrical detection of bacteria, and v) portability and on site measurements.

\section{Material and method}

\section{Devices}

The resistors used for bacteria detection applications (fig. 1) are fabricated in a classical silicon technology following a two masks process. Comb shape inter-digitated electrodes of 
the devices are made of a highly phosphorous in-situ doped amorphous silicon layer deposited by Low Pressure Chemical Vapour Deposition (LPCVD) technique at $550^{\circ} \mathrm{C}$, and solid phase crystallized by thermal annealing at $600^{\circ} \mathrm{C}$ under vacuum to get a highly in-situ doped polycrystalline silicon (polySi). Silicon nanowires (sensitive units) are locally grown on the teeth of the polySi inter-digitated electrodes by the well-known VLS mechanism at $460^{\circ} \mathrm{C}$ using gold as catalyst. In this way no patterning technique was used for elaboration of nanowires. The diameter and length of the SiNWs are $100 \mathrm{~nm}$ and more than $20 \mu \mathrm{m}$ respectively. Nanowires bridge between two adjacent teeth and thus ensure electrical connection between the two highly doped polySi electrodes (fig. 1. (b)). The potential use as high sensitive gas (ammonia) sensors of such SiNWs based resistors was previously reported $[22]$.

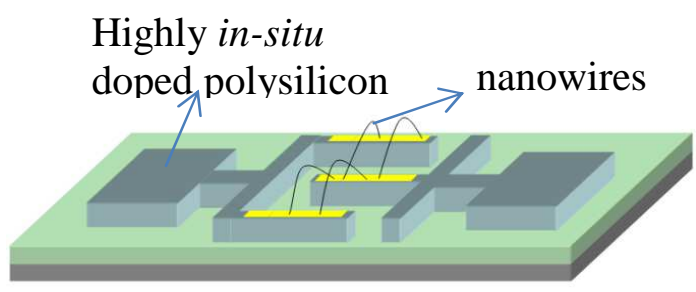

(a)

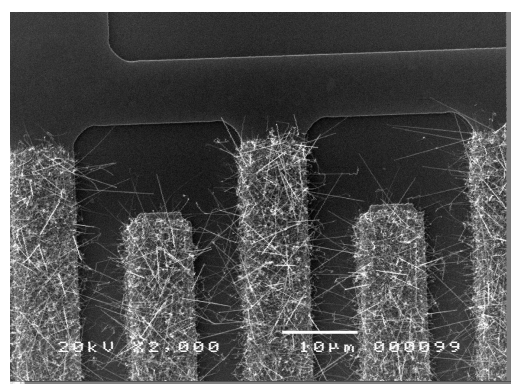

(b)

Figure 1: VLS SiNWs based resistor: schematic view (a). SEM top view observation (b).

\section{Method}


Bacteria/SiNWs interactions were studied with two types of bacterial reference strains Escherichia coli ATCC 35218 (NCTC 11954; CIP 102181) and Escherichia coli K.12 deposited on the SiNWs based resistors.

Escherichia coli ATCC 35218 bacteria deposition was carried out from serial dilutions in sterile distilled water of an overnight bacterial culture in trypticase soy broth (BBL Trypticase Soy Broth, Becton Dickinson $\left.{ }^{\circledR}\right)$ incubated at $37^{\circ} \mathrm{C}$. This culture was adjusted to $8 \times 10^{8}$ $\mathrm{CFU} / \mathrm{mL}$ by measurement of $\mathrm{OD}$ with spectrophotometer at $600 \mathrm{~nm}\left(\mathrm{OD}_{600}=0.6\right)$. Then, a serie of dilutions of bacteria in sterile distilled water was performed from $8 \times 10^{8}$ to $8 \times 10^{3}$ $\mathrm{CFU} / \mathrm{mL}$. Bacterial counts were verified by plating each dilution $(100 \mu \mathrm{L})$ on trypticase agar plates $(\mathrm{Oxoid} 囚)$, and enumerating the colonies after $24 \mathrm{~h}$ of incubation at $37^{\circ} \mathrm{C}$.

Escherichia coli K.12 bacteria deposition was carried out from serial dilutions in sterile distilled water of an overnight bacterial culture in LB broth Lennox (Difco) incubated at $37^{\circ} \mathrm{C}$. This culture was adjusted to $6 \times 10^{8} \mathrm{CFU} / \mathrm{mL}$ by measurement of OD with spectrophotometer at $600 \mathrm{~nm}, \mathrm{OD}=0,1$. Then, a serie of dilutions of bacteria was performed from $6 \times 10^{8}$ to $6 \times 10^{4} \mathrm{CFU} / \mathrm{mL}$.

After bacteria solution deposition $(30 \mu \mathrm{L})$, devices were dried at room temperature and tested $24 \mathrm{~h}$ later to avoid any moisture effect on the electrical behaviour of the resistor. Note that, considering the size of the device, a $2 \mu \mathrm{L}$ droplet could be used to limit the waste of material and to drastically decrease the drying time. It would consequently significantly reduce the response time of the sensor from $24 \mathrm{~h}$ to less than one hour. In addition, some devices submitted to a mixture of sterile distilled water and culture solution without any bacteria were used as references.

Bacteria detection was checked by measuring static I-V curves of the SiNWs based resistors using an Agilent B1500A semiconductor parameter analyser. Measurements were performed 
at room temperature on devices based on $n=20,40$, and 100 teeth of the comb shape electrode, with each tooth spaced from $\mathrm{W}=5 \mu \mathrm{m}$.

\section{Results and discussion}

Because of the SiNWs VLS process growth, for a fixed value of $\mathrm{W}$, the number of interconnected nanowires (conducting paths) between two adjacent N-type polySi teeth can change. In addition, the sizes of the nanowires are distributed over an average value, which means that the corresponding elementary resistance value can fluctuate. Thus, it might play a role in the electrical resistance measurements between two adjacent $\mathrm{N}^{+}$polySi electrodes. However, in order to simplify and because of the high number of the nanowires we assume that electrical and geometrical characteristics are identical for all interconnected nanowires. In this case, these elementary resistances, $R_{0}$, are assumed to be identical. Thus the equivalent electrical circuit of the whole resistor represented in the figure 2 results to 2 n elementary resistances connected in parallel. Therefore, the total resistance of the resistor can be expressed as the following formula:

$$
R=\frac{V}{I} \approx \frac{R_{0}}{2 n}
$$

In these conditions, macroscopic theoretical model for calculation of $\mathrm{R}_{0}$ has been previously reported by our group to estimate the average electrical resistivity of a single undoped SiNW $\left(10^{6}-10^{7} \Omega \mathrm{cm}\right)$ [23]. In this model $\mathrm{R}_{0}$ results from interconnections of nanowires and is related to the average electrical resistivity of the nanowire, $\rho_{\mathrm{NW}}$, following:

$$
R_{0}=\rho_{N W} \times K
$$


with $\mathrm{K}$ the geometrical factor depending of the total conducting paths. The high value reported of the average electrical resistivity of a single nanowire for undoped SiNWs is related to carriers trapping effect at defects located at interconnections between nanowires and induced by gold impurities at the surface of the nanowires.

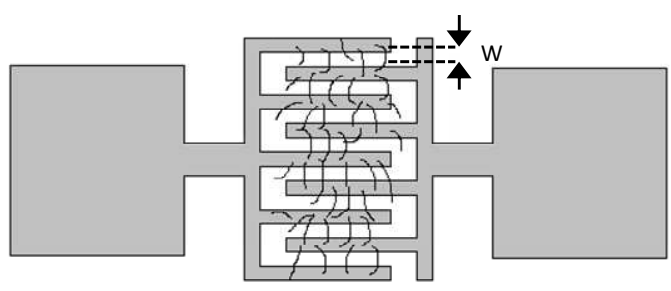

$\mathrm{n}$

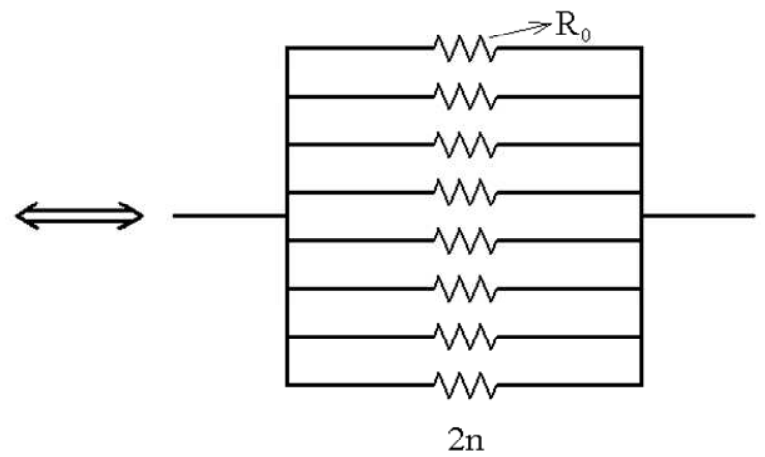

Figure 2: Equivalent circuit diagram of SiNWs based resistors

Electrical characterization for three types of resistors with $n=20,40,100$ are reported in the figure 3. Plots show that the current level through the global electrical resistance increases as the number of teeth of the interdigitated electrodes increases. These results are related to the linear variations of the conductance $\left(\mathrm{G}=\mathrm{I} / \mathrm{V} \approx 2 \mathrm{n} / \mathrm{R}_{0}\right)$ with $\mathrm{n}$ reported in the inset of the figure 3 (for an average value $\mathrm{R}_{0} \approx 1.9 \times 10^{9} \Omega$ ), and validate the equivalent electrical model given by (1).

Interaction of bacteria with the surface of materials is mainly controlled by the charge effects and hydrophobic properties between bacteria and materials [24]. In particular, the adhesion can occur when the van der Waals forces of attraction between the membrane of the bacteria and the surface of the material outweigh the electrostatic repulsion forces [25, 26]. 


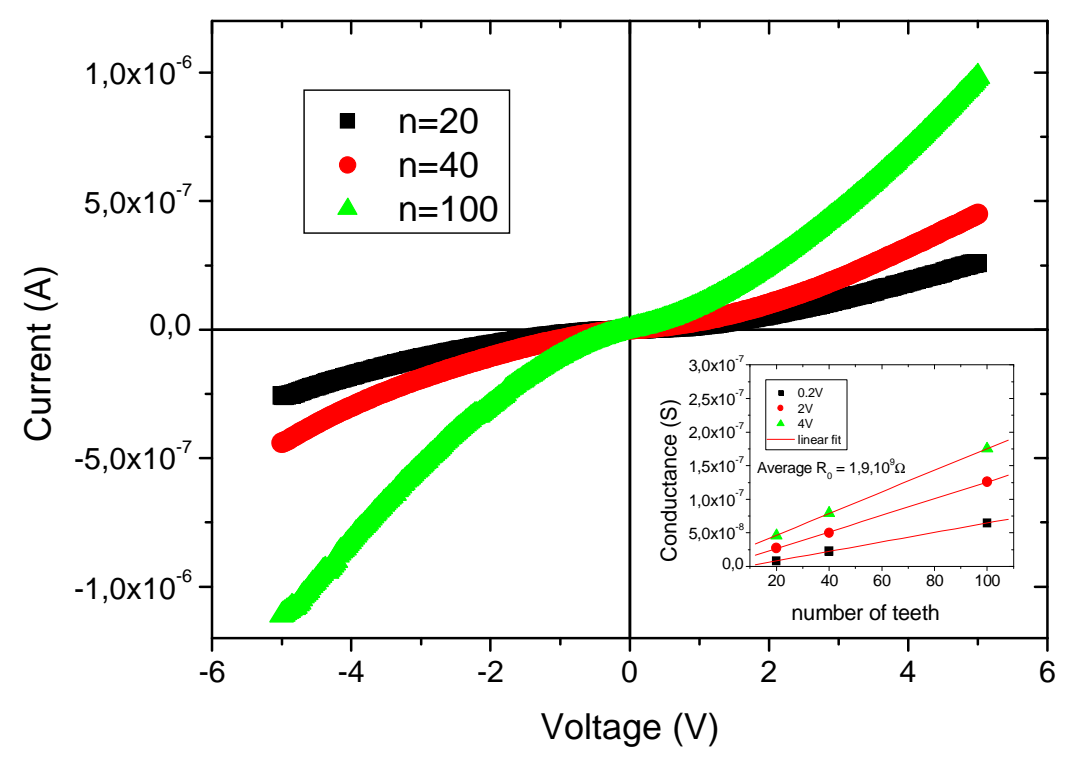

Figure 3: I-V characteristics of the SiNWs based resistors made of interdigitated comb electrodes with 20, 40 and 100 teeth. Inset: electrical conductance variations with the number of teeth at $0.2 \mathrm{~V}, 2 \mathrm{~V}$ and $4 \mathrm{~V}$.

After bacteria immobilization on the device, bacteria interaction with SiNWs is firstly analysed by SEM observations (fig. 4). The bacteria optical count has not been performed in this study. Interestingly, in our case, pictures clearly show that bacteria are mainly attached into the silicon nanowires mesh rather than in other parts of the device. This observation shows the interest to use a 3D SiNWs tangled mesh to promote bacteria immobilization and thus detection. Functionalization of active parts for detection, usually based on sophisticated chemical steps, is a common method to allow immobilization and identification of chemical of biochemical species [27]. However, in our case families of bacteria cannot be identified. 


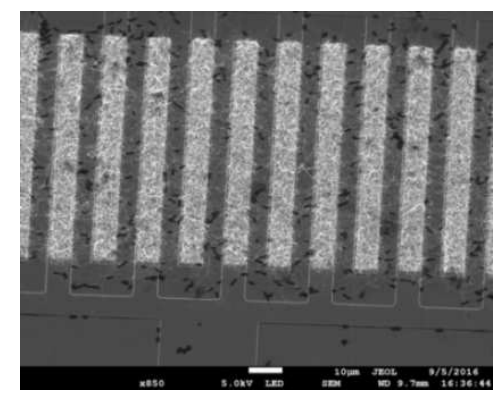

(a)

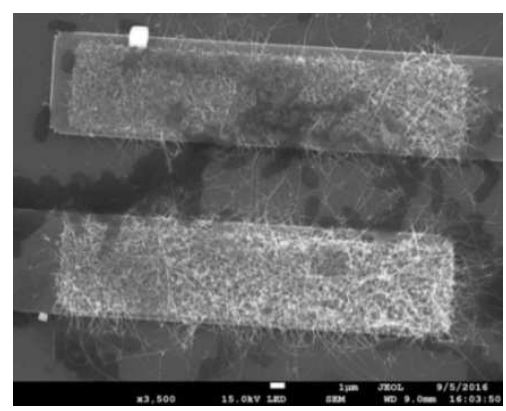

(b)

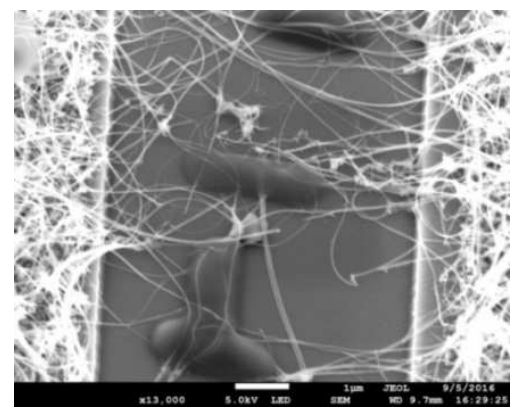

(c)

Figure 4: SEM pictures of bacteria (dark areas) hanged into SiNWs network of the resistor shown at three different scales

Detection was studied for the two bacteria Escherichia coli, ATCC 35218 and K12 with different ranging concentrations $\left(8 \times 10^{8}\right.$ to $8 \times 10^{3} \mathrm{CFU} / \mathrm{mL}$ and $6 \times 10^{8}$ to $6 \times 10^{4} \mathrm{CFU} / \mathrm{mL}$ respectively). Electrical effect of bacteria immobilization is then checked by electrical 


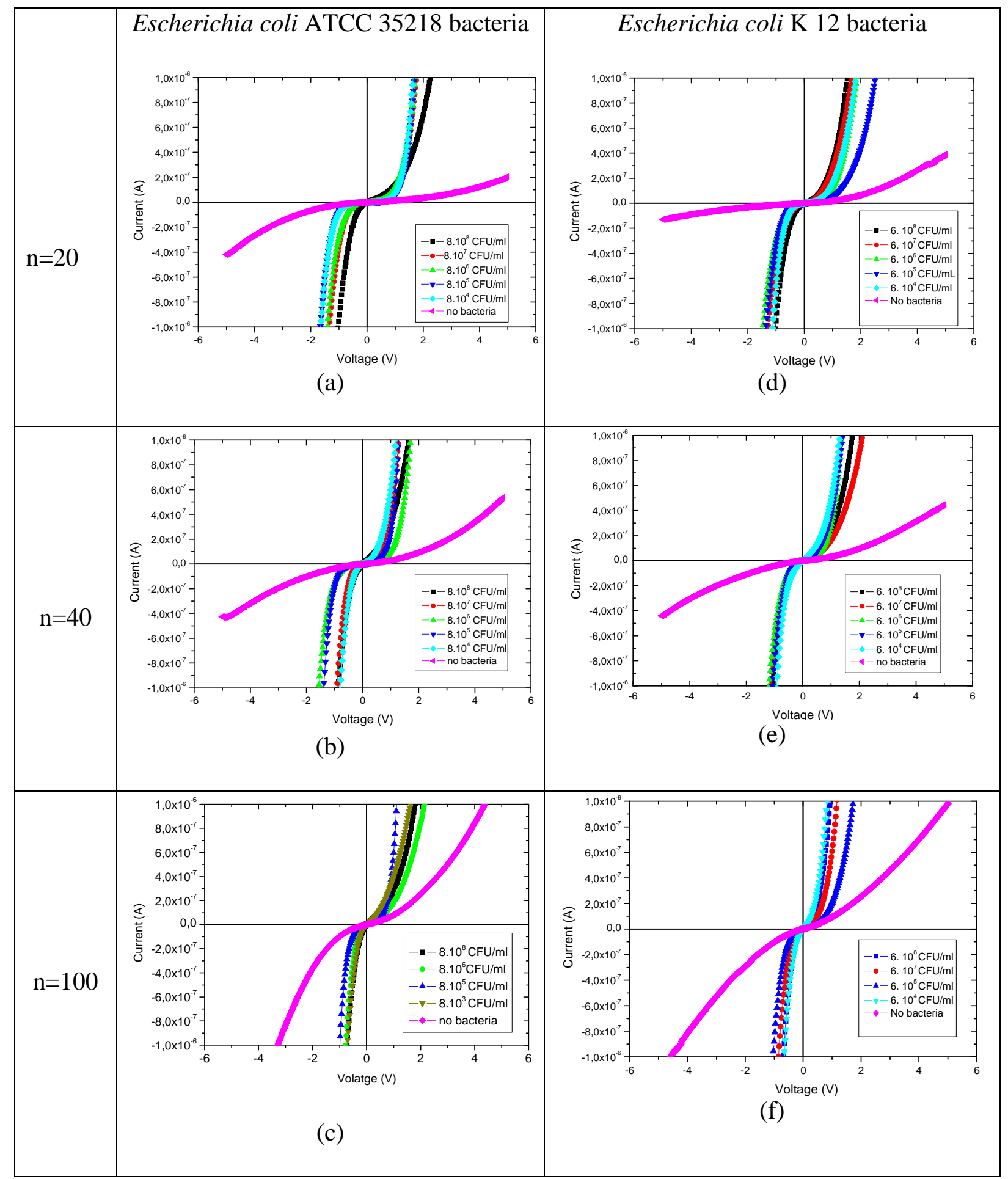

Figure 5: I-V curves of the SiNWs based resistors with $\mathrm{n}=20,40,100$ teeth and $5 \mu \mathrm{m}$

interspacing, after Escherichia coli ATCC 35218 immobilization (a), (b), (c), and

Escherichia coli K12 bacteria immobilization (d), (e), (f). Curves for devices submitted to a

mixture of distilled water and culture solution without bacteria are given as reference. 
measurements performed on SiNWs based resistors. As shown in the figure 5, for the two types of bacteria I-V curves exhibit a drastic increase of the current corresponding to a lowering of the $\mathrm{R}$ value of the resistor due to the presence of bacteria. This phenomenon is probably due to the negative charge of their peptidoglycan (PG) based membrane [27, 28]. Indeed, two main types of bacteria are listed related to their membrane: Gram positive (+) and Gram negative (-) bacteria. For the Gram-positive bacteria, membrane contains a thick (20$50 \mathrm{~nm}$ ) PG layer attached to teichoic acids [29]. In the case of Gram-negative bacteria as $E$. Coli, the membrane is made of a thin PG layer covered by an extern membrane containing lipopolysaccharides components, responsible of a higher negative charge of the bacteria [30]. To explain the decrease of the global electrical resistance due to the capture of bacteria three effects can be invoked. One first explanation could be a transfer of charges (electrons) of the bacteria into the nanowires which fill the traps previously mentioned, and thus could and contribute to the decrease of the electrical resistivity of the nanowires [23]. Another possible reason is that the electrically charged bacteria may behave as biological gate resulting as wellknown field effect $[13-15,17]$ on the SiNWs. At last, other explanation is that bacteria may act as additional conducting paths randomly distributed between teeth thanks to hooking effect of bacteria into the SiNWs network. This phenomenon would contribute to the variations of $R_{0}$ values, $\Delta R$, strongly dependent on the number of bacteria hanged between two adjacent teeth (see fig. 6). Based on these three considerations, further investigations for a well understanding of the carrier transport in these devices in relation with bacteria and nanowires interactions must be conducted for consideration in the model given by (2). 


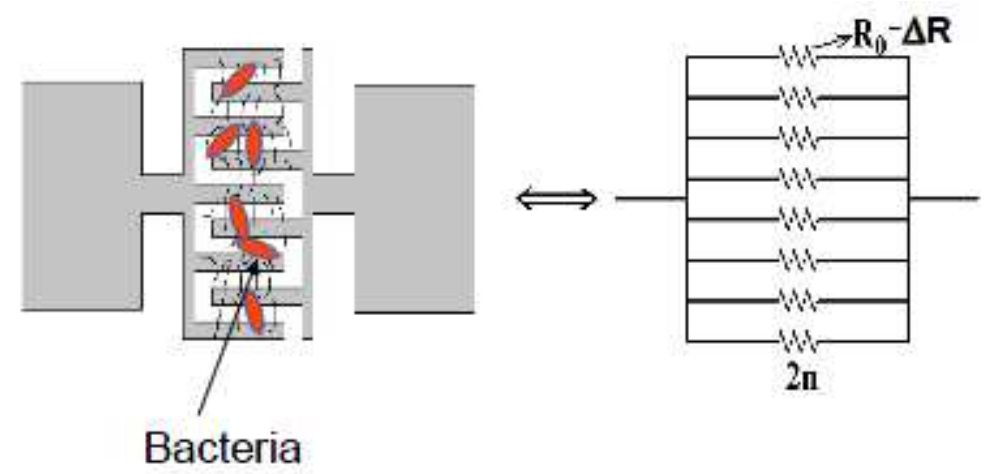

Figure 6: Illustration of the electrical resistance change with bacteria interaction

Furthermore, as shown in the figures $\mathrm{S} 1$ reported in the supplementary material, no significant change of the global electrical resistance (of the resistor) was observed at low bias voltages $(-1 \mathrm{~V}<\mathrm{V}<+1 \mathrm{~V})$ with the bacteria concentration, and thus the domain of interest for bacteria detection corresponds to the highest bias voltages. In this way, we reported in the figure 7 the values of the global resistance measured at $\pm 4 \mathrm{~V}$ for the two types of detected bacteria. No tendency can be clearly observed in function of the number of teeth and neither in function of the studied bacteria concentrations. Such unexplicated results must be related to the intricate model of the global electrical resistance of the device with the presence of bacteria.

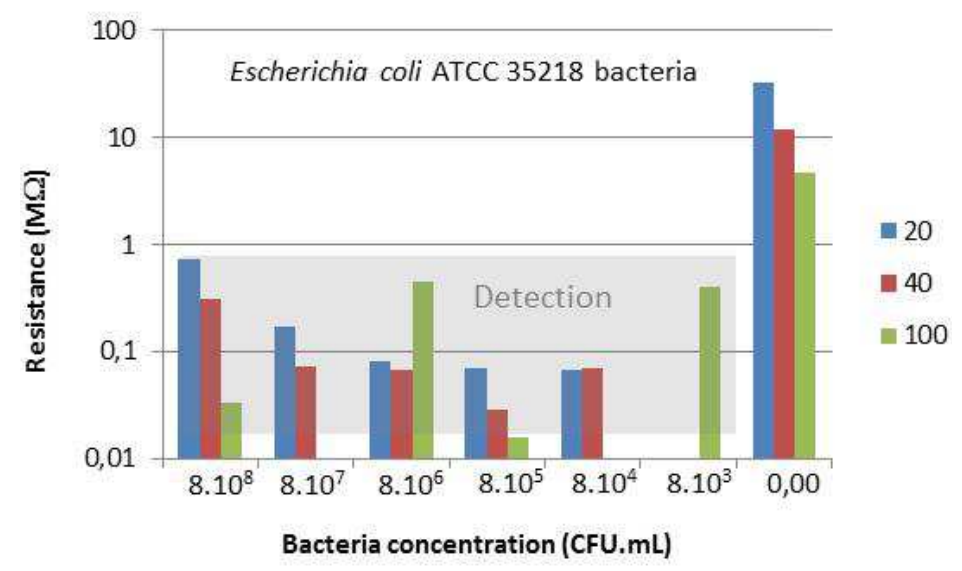

(a) 


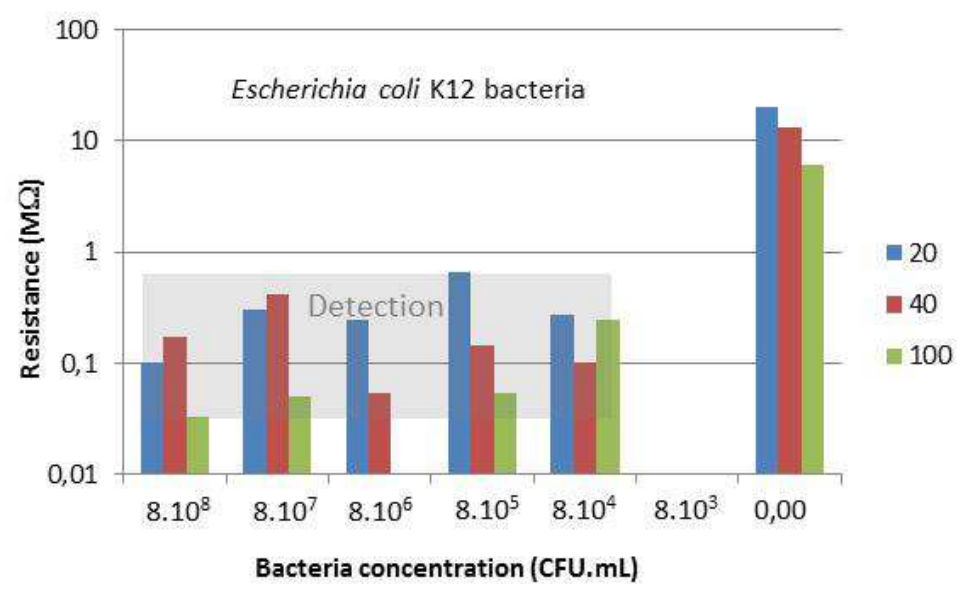

(b)

Figure 7: Histograms of the global electrical resistance of the sensor made of 20, 40, 100 teeth interdigitated electrode measured at $\pm 4 \mathrm{~V}$ for (a) Escherichia coli ATCC 35218, (b)

Escherichia coli K.12. Grey area: detection range value

Because the performances of a bacteria sensor are strongly related to its abilities for quantitative recognition of target analytes, further studies in function of the size, the quantity, and the type of targeted bacteria have to be carried out for applications of our SiNWs based resistors as selective bacteria sensors. Nevertheless, sensing properties of our SiNWs based resistors have s low detection limit, working range and time analysis to many others bacteria detection techniques (Enzyme Linked ImmunoSorbent Assay-ELISA, PCR, QCM-Quartz Crystal Microbalance immunosensor, impedimetric, amperometric...) [31, 32].

\section{Conclusion}

In this work, investigations on a SiNWs based resistor were carried out to study the potential development of a sensitive real-time detection bacteria sensor, fabricated by a simple low-cost fabrication and compatible CMOS silicon technology, using VLS SiNWs as sensitive 
elements. Such a technology takes advantages of both benefits at nanoscale and microtechnology for miniaturization and integration on microsystems, and of the use of SiNWs network to favour bacteria hanging to increase the sensitivity for detection of bacteria. The detection is based on the electrical measurement. The resistor showed its ability for bacteria detection (Escherichia coli ATCC 35218 and K12) at concentration as low as $6 \times 10^{3}$ $\mathrm{CFU} / \mathrm{mL}$. Since the change into electrical resistances values of the device were not correlated with bacteria concentrations, it could be used only for yes/no diagnosis. Further studies are needed to use the SiNWs based resistor as quantitative detection system and at lower detection limit. However, because such device is easy to use, reagent-less, and portable, it has the potential to be used as further detection tool for biosafety.

\section{References}

[1] S. P. Diggle, A.S. Griffin, G. S. Campbell, S. A. West Cooperation and conflict in quorum-sensing bacterial populations. Nature, 450(7168), (2007) 411-414.

[2] A. K. Bej, M. H. Mahbubani, J. L. Dicesare, R. M. Atlas, Polymerase chain reaction-gene probe detection of microorganisms by using filter-concentrated samples, Appl. Environ. Microbiol. 57 (12), (1991) 3529-3534

[3] E. Leoni, P. P. Legnani, Comparison of selective procedures for isolation and enumeration of Legionella species from hot water systems, J. Appl. Microbiol. 90, (2001) 27-33

[4] H. Gu, K. Xu, C. Xu, B. Xu, Biofunctional magnetic nanoparticles for protein separation and pathogen detection, Chem. Commun. 9, (2006) 941-949

[5] W. S. Shell, M. L. Sayed, F. M. G. Allah, F. E. M. Gamal, A. A. Khder, A. A. Samy, A. H. M. Ali Matrix-assisted laser desorption-ionization-time-of-flight mass spectrometry as a reliable proteomic method for characterization of Escherichia coli and Salmonella isolates. 
Vet World. 2017 Sep;10(9):1083-1093. doi: 10.14202/vetworld.2017.1083-1093. Epub 2017 Sep 19. PubMed PMID: 29062198; PubMed Central PMCID: PMC5639107.

[6] A.K. Deisingh, M. Thompson Can. Biosensors for the detection of bacteria, J. Microbiol. 50, (2004) 69-77

[7] H. Tang, W. Zhang, P. Geng, Q. Wang, L. Jin, Z. Wu, M. Lou, A new amperometric method for rapid detection of Escherichia coli density using a self-assembled monolayerbased bienzyme biosensor,. Anal. Chim. Acta 562, (2006) 190-196

[8] S. M. Radke, E. C. Alocilja, A high density microelectrode array biosensor for detection of E. coli O157:H7, Biosens. Bioelectron. 20, (2005)1662-1667

[9] S. M. Radke, E. C. Alocilja, A microfabricated biosensor for detecting foodborne bioterrorism agents, IEEE Sens. J. 5 (4), (2005) 744-750

[10] M. Varshney, Y. Li, Interdigitated array microelectrode based impedance biosensor coupled with magnetic nanoparticle-antibody conjugates detection for Escherichia coli O157:H7 in food sample, Biosens. Bioelectron. 22, (2007) 2408-2414

[11] P. Bergveld, Thirty years of ISFETOLOGY: What happened in the past 30 years and what may happen in the next 30 years, Sens. Actuators B 88, (2003) 1-20

[12] Z. Mahummad-Tahir, E.C. Alocilja A conductometric biosensor for biosecurity, Bios. Bioelectron. 18, (2003) 813-819

[13] Y. Cui et al., Nanowire nanosensors for highly sensitive and selective detection of biological and chemical species. Science, 293(5533) (2001) 1289-1292.

[14] Z. Li, Y. Chen, X. Li, T. I. Kamins, K. Nauka, R.S Williams Sequence-Specific LabelFree DNA Sensors Based on Silicon Nanowires, Nano Letters 4 (2), (2004) 245-247

[15] X. Chen, C. K. Y. Wong, C. A. Yuan, G. Zhang, Nanowires based gas sensor, Sensors and Actuat. B, 17, (2013) 178-195

[16] R. He, P. Yang, Giant piezoresistance effect in silicon nanowires, Nature Nanotech. 1, (2006) 42-46 
[17] N.N. Mishra, W. C. Maki, E. Cameron, R. Nelson, P. Winterrowd, S. K. Rastogi, B.

Filanoski, G. K. Maki Ultrasensitive detection of bacterial toxin with silicon nanowire transistor Lab. Chip 8, (2008) 868-871

[18] B. Le Borgne, A. C. Salaun, L. Pichon «Silicon nanowires based resistors for bacteria detection », Eurosensors (2017) 1, 496

[19] M. Lee, Y. Jeon, T. Moon, S. Kim Top-Down Fabrication of Fully CMOS-Compatible Silicon Nanowire Arrays and Their Integration into CMOS Inverters on Plastic, Nano Lett. 2, 5(4), (2011) 26-29

[20] A. I. Hochbaum, R. Fan, R. He, P. Yang Controlled Growth of Si Nanowire Arrays for Device Integration, Nano Lett. , 5 (3), (2005) 457-460

[21] R. S. Wagner, W. C. Ellis Vapor-liquid-solid mechanism of single crystal growth, Appl. Phys. Lett., 4(5), (1964) 89-91

[22] F. Demami, L. Ni, R. Rogel, A.C. Salaun, L. Pichon Silicon nanowires based resistors as gas sensors Sensors and Actuators B: Chemical vol 170, (2012) 158-162

[23] L. Pichon, R. Rogel, E. Jacques Electrical properties of phosphorus in-situ doped Aucatalyst vapor liquid solid silicon nanowires Journ. Appl. Phys. 118, (2015) 185701

[24] T.R. Neu, K. C. Marshall. Bacterial polymers: physicochemical aspects of their interactions at interfaces. J. Biomater. Appl. 5 (1990) 107-133.

[25] K. C. Marshall Adsorption and adhesion process in microbial growth at interfaces. Adv. Colloid Interface Sci. 25(1986) 59-86

[26] H. H. M. Rijnaarts, W. Norde, E. J. Bouwer, J. Lyklema, A. J. B. Zehnder. Reversibility and mechanism of bacterial adhesion. Colloids Surf. B: Biointerface 4 (1995) 5-22

[27] Y. C. Lu, Y. S. Chuang, Y. Y. Chen, A. C. Shu, H. Y. Hsu, H. Y. Chang, T. R. Yew Bacteria detection utilizing electrical conductivity, Bios and Bioelec. 23, (2008) 1856-1861 
[28] B. Gottenbos, D. W. Grijpma, H. C. van der Mei, J. Feijen, H. J. Busscher, Antimicrobial effects of positively charged surfaces on adhering Gram-positive and Gramnegative bacteria. Journal of antimicrobial chemotherapy, 48(1), (2001) 7-13

[29] J. R. Scott, T. C. Barnett Surface proteins of gram-positive bacteria and how they get there. Annu. Rev. Microbiol. 60 (2006) 397-423

[30] I. S. Roberts The biochemistry and genetics of capsular polysaccharide production in bacteria. Annu. Rev. Microbiol. 50 (1996) 285-315

[31] O. Lazcka, F. J. Del Campo, F. X Minoz, Pathogen detection : A perspective of traditional methods and biosensors, Biosen. And Biolect. 22 (2007) 1205-1217

[32] A. Ahmed, J. V. Rushworth, N. A. Hirst, P. A. Millner, Biosensors for whole-cell bacteria detection, Clinic. Microbiol. Rev. 27-3 (2014) 631-646 